\title{
THE SOVEREIGN TRICKSTER
}




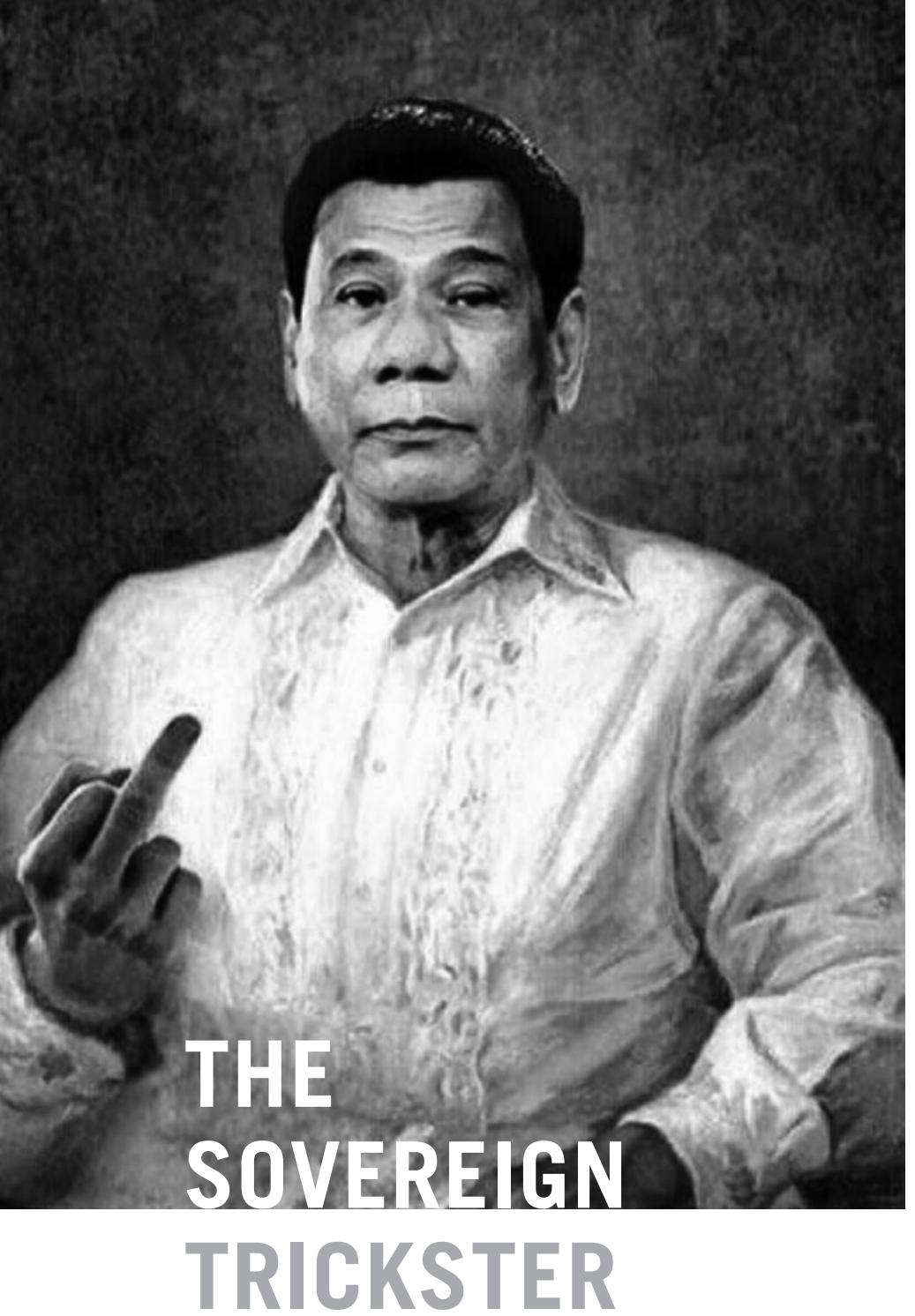

Vicente L. Rafael 
DEATH AND

LAUGHTER IN THE AGE OF DUTERTE 
Frontispiece. Internet meme from a Twitter parody account illustrating Duterte as a sovereign trickster, combining the traditional rendering of presidential figures with a universal image of vulgarity. From "Rodrigo Duterte @DigongDU30, 16th President of the Philippines, The Punisher, Master of Profanity, Great Leader, Parody Account." https://twitter.com/DigongDU3O.

(C) 2022 Duke University Press. All rights reserved.

Printed in the United States of America on acid-free paper $\infty$ Designed by Courtney Leigh Richardson

Typeset in Whitman and Trade Gothic by Copperline Book Services

Library of Congress Cataloging-in-Publication Data

Names: Rafael, Vicente L., author.

Title: The sovereign trickster: death and laughter in the age of Duterte / Vincente L. Rafael.

Description: Durham: Duke University Press, 2022. |

Includes bibliographical references and index.

Identifiers: LCCN 2021015724 (print)

LCCN 2021015725 (ebook)

IS BN 9781478015185 (hardcover)

IS BN 9781478017790 (paperback)

ISBN 9781478022411 (ebook)

Subjects: LCSH: Duterte, Rodrigo Roa, 1945- | PresidentsPhilippines-Biography. | Extrajudicial executions-Philippines. |

Philippines-Politics and government-21st century. | BISAC:

History / Asia / Southeast Asia

Classification: LCC Ds686.616. D88 R343 2022 (print)|

LCC DS686.616. D88 (ebook) | DDC 959.905/3092 [в]—dc23

LC record available at https: //lccn.loc.gov/2021015724

LC ebook record available at https: //lccn.loc.gov/2021015725

COVER ART: An alleged drug dealer-and Duterte supporterarrested after a buy-bust operation in a slum area in Manila, September 28, 2017. Courtesy Noel Celis/AF P via Getty Images. 
For Lila 
This page intentionally left blank 